\title{
Visitor Flow and Spatial Collection of Learning Museum, Universitas Negeri Malang
}

\author{
$1^{\text {st }}$ Ari Sapto \\ History Department, Faculty of Social Science \\ State University of Malang \\ Malang, Indonesia \\ $2^{\text {nd }}$ Ulfatun Nafi'ah \\ History Department, Faculty of Social Science \\ State University of Malang \\ Malang, Indonesia \\ ulfatun.nafi'ah.fis@um.ac.id \\ $3^{\text {rd }}$ Blasius Suprapta \\ History Department, Faculty of Social Science \\ State University of Malang \\ Malang, Indonesia
}

\author{
$4^{\text {th }}$ Joko Sayono \\ History Department, Faculty of Social Science \\ State University of Malang \\ Malang, Indonesia \\ $5^{\text {th }}$ Moch Nizam Alfahmi \\ History Department, Faculty of Social Science \\ State University of Malang \\ Malang, Indonesia \\ $6^{\text {th }}$ Hawiki Renalia \\ History Department, Faculty of Social Science \\ State University of Malang \\ Malang, Indonesia \\ renalisten@gmail.com
}

\begin{abstract}
Spatial development of the Universitas Negeri Malang Learning Museum spatial museum The spatial planning museum is prepared by considering the type of collection about learning developed by the Universitas Negeri Malang. Universitas Negeri Malang Learning Museum translates multidisciplinary which contains diverse collections and can be made as a learning feature of each faculty. This museum helps save, store and restore shared memories (collective memory). In carrying out its activities, the museum works closely with the community until finally, it can prove cultural identity. To that end, the spatial layout of the museum's collection is compiled with past history by providing a future through designs that use developments so that people can find relevance to the past and present. The museum is also equipped with a flow of visitors to see the full design of the room. This study uses analytical methods that contain problems, field data collection, literature, typology, analytical programming, synthesis, design schematics, concept preparation, and design realization. The results of this study are the form of spatial collection and the flow of visitors to the Universitas Negeri Malang learning museum concretely.
\end{abstract}

Keywords: visitor flow, spatial planning, collection, learning museum, University museum

\section{INTRODUCTION}

The museum has a long history, going back to the 3rd century BC when the first known museum opened at Alexandria University in Egypt. However, over the years, museum culture has spread to almost every part of the world and now it is not common to find any country that does not have a museum, no matter how small. This implies that the concept of the museum has become a global concept that survived in the 20th century [1]. So it would not be an exaggeration to say that museums are an important or even mandatory part of a country's presence.

Etymologically the word "museum" comes from the ancient Greek language "muze" which means a temple dedicated to the Muses (god of art and science) and is a place of education and art. In the modern era, according to the results of the congress of the ICOM (International Council of Museums), an international organization under UNESCO, the definition of "Museum is an institution/institution that is permanent, not looking for profit (non-profit) in serving the community, open to the public, by making an effort to obtain, conserve, research, communicate and exhibit tangible objects to the public for the needs of study, education, research and entertainment [2]. Meanwhile, according to government regulations No. 19 of 1995, "Museums are institutions for storing, maintaining, securing, and utilizing material evidence of humans as well as nature and the environment to support efforts to protect and preserve the nation's cultural wealth.

The objects stored in the museum are actually selected objects. He was chosen to be the representative of the past in the present, and the future before us. The museum is a deposit of the achievements of all fields of human life [3]. The museum as an 
qualitative, quantitative, and multimethod approaches [7]. The

institution tells the story of humans throughout the world and how humans have survived in their environment for years. The museum is the home of things created by nature and by humans and in our modern society, it accommodates the cultural soul of the nation [1]. That the existence of a museum has an educational function [4]. Other functions of the museum as a means of social interaction, add insight, get entertainment and recreational facilities [5]. For this reason, the most important function of the Learning Museum in Universitas Negeri Malang is to provide learning for the community.

The significance of the museum's presence is often underestimated. The museum is considered an ancient and boring place. This is reflected in the low interest of people coming to the museum. The concept of early (old) museums is elitist, unattractive, and aloof because it only encourages educated people to visit them, the general public becomes estranged [1]. But the meaning of a museum should be more than just something ancient. To convey the importance of the museum to the public, a breakthrough is needed to make the ancient impression of the museum be removed. This is important because museums need to adjust to the times. Therefore the concept of a new museum becomes an important requirement in the future development of the museum.

The concept of the old museum into a new museum that is more modern, one of which can be seen with the arrangement of the exhibition space exhibiting an interesting and communicative museum collection following the technological developments and developments of the times. The learning museum of the Universitas Negeri Malang was developed by bringing the concept of a new museum and adjusting the needs of the community as a target audience. Spatial design is made by considering a good layout design, by looking at the suitability of the atmosphere of the room, air conditioning, good lighting, and considering the circulation of visitors.

The learning museum carries the design of exhibiting collections by having the concept to package or arrange collection objects that are exhibited and presented to those who see it. The presentation of the museum must change the paradigm, that a collection must be oriented by giving meaning and knowledge to the community to find their own identity and cultural roots [6]. Therefore, this article aims to examine in more depth about: 1) Development of Spatial Collection of Universitas Negeri Malang Learning Museum collections chronologically and communicatively with a variety of museum collection objects; 2) Arrangement of UM Learning Museum Visitor flow.

\section{METHOD}

This research uses design methodology in a series of work processes, namely the analysis process, the synthesis process, and the evaluation of results. Research approaches in the field of fine arts developed into several types of approaches, namely design stages used in the design of the museum's design depart from a phenomenon or issue underlying the objectives, and concerning the basic arrangement of the museum's exhibition system using a qualitative approach.

The design stage of the Universitas Negeri Malang Museum exhibition design is to use the analytical method. This is done because the interior design process has a relatively high complexity of problems. This method is the result of room design is influenced by the process of determining the problem. Field data collection, literature study, typology, programming analysis, design schematics, conceptualization, and design realization [8].

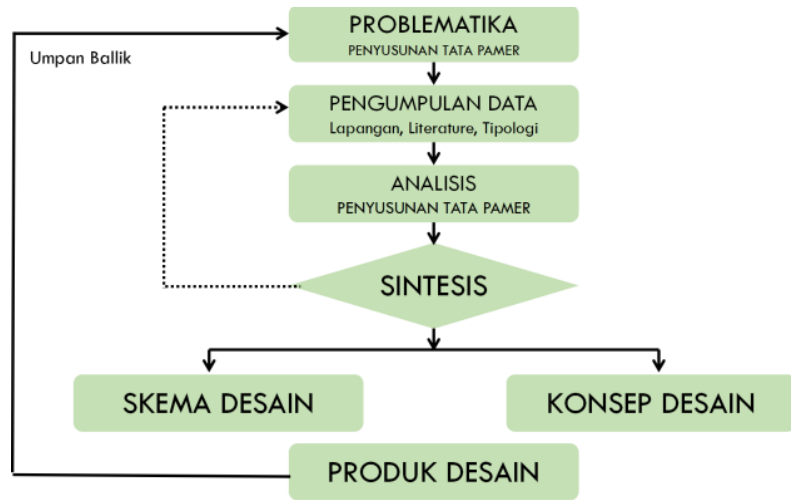

Fig. 1. Chart of Design Making Source: modified from Santosa (2005)

\section{RESUlTS AND DISCUSSION}

\section{A. Museum Pembelajaran Exhibition}

The museum exhibition is related to the presentation of collection objects that will be seen by visitors. Mention some things that signify the success of an exhibition, namely: making the subject look alive, an explanation that is easily and quickly captured, having something for all ages, impressive, clearly having to start and where to continue (circulation), using modern display techniques that help visitors learn objects, use experiences and things that are easily recognizable to reinforce an intent, and the last is equipped with a complete object display [9].

The Universitas Negeri Malang Learning Museum Room is a museum room that deals with the design of museum exhibits and museum exhibit material. In the distribution of the order of the Museum Room, the Museum of Learning, Universitas Negeri Malang followed the research studies based on comparative study studies in several museums such as the Indonesian National Museum, Jakarta, the Bandung National Education Museum, the Bandung Geology Museum, the Bandung Sate Building Museum, the Indonesian Education 
museum collection materials (Figure 3). This room was once a warehouse archive room since FKIP UNAIR Malang to IKIP Malang. It is located near the administration room so it is easy for managers to reach. Therefore it is suitable to be used according to their needs in managing collection objects.

In this space, the collection is treated as an inactive file. Inactive records management can be achieved well if inactive records management goes well, the archival organization of the processing unit (Central File), the filing unit (Records Center), and the archival institution can function properly [11]. Therefore the management of the Universitas Negeri Malang Learning Museum implements management, including processing, data collection, and storage management.

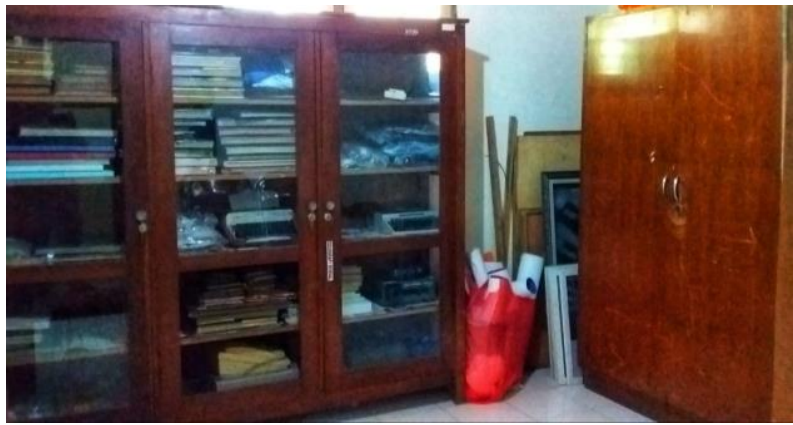

Fig. 3 Strorage Warehouse Room Museum Learning State University of Malang

\section{3) Museum Rooms Administration Room}

This space is intended to control the management of museum visitor management as well as the museum administration room. Here the museum administrator controls everything related to the museum. Museum administrators make choices, develop and implement plans so that museum collections can be preserved and museum visitors can have interesting experiences with artifacts and specimens from collections [12]. For this reason, this space has a vital role in running the museum, so it is necessary to select a special room.

The choice of space is based on building potential and administrative requirements. Its location is close to the Storage Warehouse Room making it easier for managers in terms of mobility. In this space, there are several facilities aimed at supporting all forms of museum management. To maximize the existing space in this room made into two floors, the first floor is used for technical work purposes and the second floor is for meeting and coordination.

\section{4) Room Orientation Exhibition History of}

The Room of Exhibition Orientation History of Universitas Negeri Malang explains about the history of Universitas Negeri museum exhibit collections before it is exhibited in the museum exhibit space and at the same time as a place for restoration of 
Malang since its establishment, namely since PTPG until it changed to IKIP STATE MALANG. In the next trip, Based on the Republic of Indonesia's Presidential Decree Number 93 of 1999 IKIP Malang changed to Malang State University. The narration about the history of Universitas Negeri Malang was aired in audiovisual form with a duration of 10 minutes.

This space emphasizes the presence of university history as part of the orientation of the museum's material collection presentation. So that visitors can be interested to follow the flow that is presented, therefore atmosphere management becomes important. The atmosphere or atmosphere that must be built in a museum. The atmosphere of the exhibition space must be made in such a way as to bring an exhibition to life in accordance with the context of the exhibit [9].

To enliven the atmosphere that attracts visitors, this space is designed to be able to present the historical atmosphere of the Universitas Negeri Malang through a video history of the University and combined with several infographics and other collections. This is closely related to the image of identity that is built both museums in small landscapes and universities in large landscapes. Through narration, stories, events, and memories, one can feel the connection to the environment that forms an identity [13].

Spatial Design Design Exhibition Room Orientation History of Universitas Negeri Malang consists of walls in the form of boot screens, picture walls of the establishment of PTG Malang, IKIP Negeri Malang, Universitas Negeri Malang and five main pillars of Universitas Negeri Malang. Spatial Design Orientation Design History of SUniversitas Negeri Malang can be seen in Figure 4.

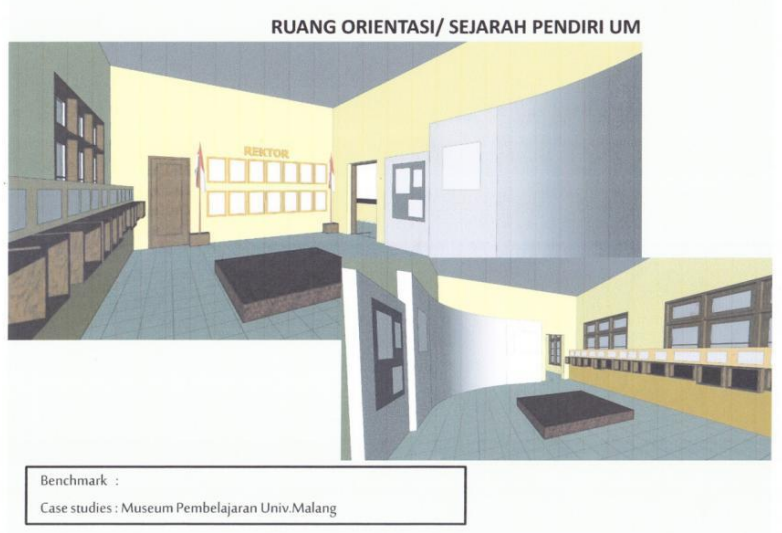

Fig. 4. Spatial Orientation Design Design History of State University of Malang

5) Room of History Exhibition of Malang State University The Room of History Exhibition of Universitas Negeri Malang is related and is a continuation of the Room
Exhibition Room of Universitas Negeri Malang which contains the historical narration of the rector's leadership from PTPG Malang until it turns into IKIP NEGERI MALANG and apart from its parent namely Airlangga University, Surabaya. In the next trip based on the Republic of Indonesia Presidential Decree Number 93 of 1999, IKIP Malang changed to Universitas Negeri Malang.

The Room of History Exhibition ofUniversitas Negeri Malang displays photographs of a number of chancellors who had led the Universitas Negeri Malang at the time of the establishment of PTPG Malang to become the State Teachers' College of Malang and became Universitas Negeri Malang. In relation to that, the narratives of the life of the chancellor were presented in the form of artifactual in the form of the chancellor's desk, rector's chair, chancellor's cabinet, rector's typewriter and all kinds of clothes the rector had worn. This is to make the atmosphere felt by visitors seemed closer to the chancellor who had served.

Room Design Design History of Universitas Negeri Malang can be seen in figure 5 , as follows:

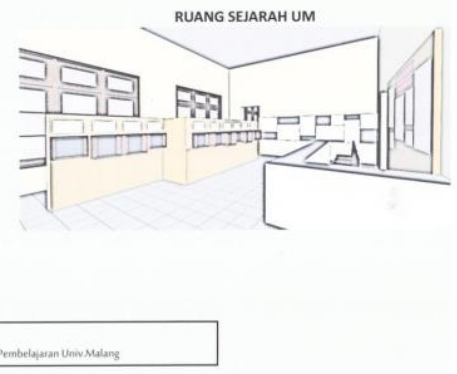

Fig 5. Room Design Exhibition History of State University of Malang

6) Room Exhibition Profile Of State University of Malang The Room of Exhibition of the Universitas Negeri Malang's Achievement Profile is a continuation of the Room of Exhibition of the History of the Universitas Negeri Malang and contains a narrative about all forms of achievement related to the work of the Universitas Negeri Malang on the national and international scene. In this connection, this space presents a narrative of various achievements that have been achieved by the Universitas Negeri Malang so that it contains artifacts that narrate it. The contents of artifactual objects include all forms of awards, trophies, graduation toga, opening ceremony and symbols of Malang State University.

To support the exhibition material in the form of the achievement profile of the Universitas Negeri Malang, the display that was presented emphasized the lighting and back sound which added a high and magnificent impression. The lighting design must be adjusted to the atmosphere of the room or atmosphere you want to display [9]. Therefore the arrangement of light used in the form of emphasis on the object 
technique and the selection of a golden yellow color that supports. The background that is used contains the chanting of Mars Universitas Negeri Malang to increase the impression of a solemn atmosphere.

Designs Museum Rooms Room Design Exhibition of State University of Malang are as follows (Figure 6):

RUANG PRESTASI

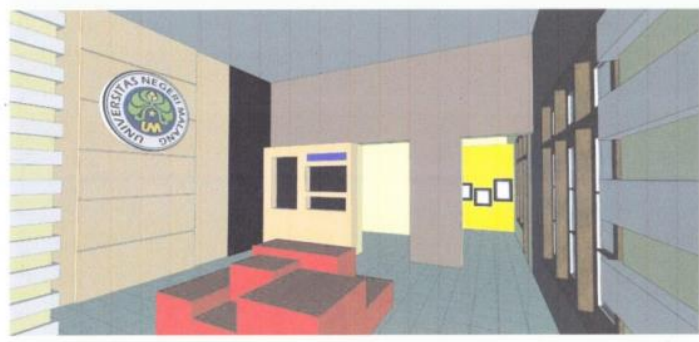

Case studies : Museum Pembelajaran Univ.Malang

Fig. 6. Room Design Room Design Exhibition Profile of State University of Malang

\section{7) Curriculum Exhibition Room 1}

Curriculum Exhibition Room 1Curriculum Room Exhibition 1 is a continuation of the Room Design Exhibition Room of Universitas Negeri Malang which narrates several figures related to learning innovation as long as Universitas Negeri Malang takes part in the world of education. In connection with this, it contains the figures for the scholarship of Universitas Negeri Malang who contribute directly in the field of learning innovation both at national and international levels. Narratives related to this are manifested in the form of photos of figures and academic work of educational figures in Universitas Negeri Malang.

The exhibited material is lined up between the work and the character who made the work. The layout is arranged in the form of a tunnel so that visitors who see will focus on one material to another. When visitors are focused, their interest will increase. The museum will be more interesting and easier to enjoy when the museum has a groove in organizing its spaces. Museums that do not have grooves tend to be monotonous and confusing if there is no signage [13].

Curriculum Design Room Design 1 can be seen in Figure 2 and Figure 6 as follows:

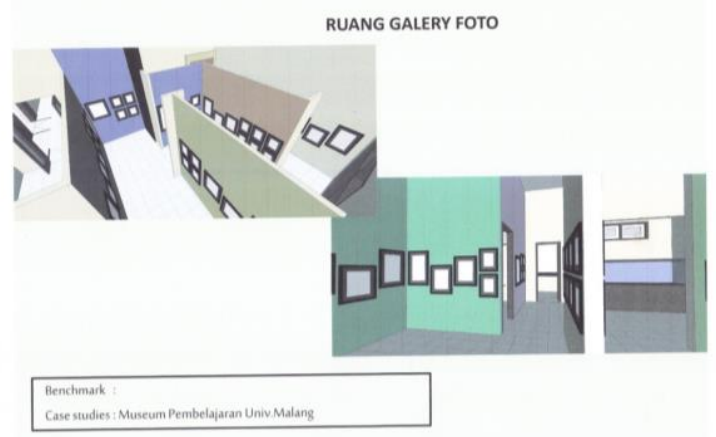

Fig. 7. Spatial Planning Design Curriculum 1 Malang State University

8) Curriculum Exhibition Room 2 and 3

Curriculum Exhibition Room 2 narrates the various curricula that exist in Universitas Negeri Malang faculties, namely the curriculum of the Faculty of Education, Faculty of Literature, Faculty of Mathematics and Natural Sciences, Faculty of Social Sciences and Faculty of Economics. In this connection also narrated about the superior curriculum and displayed in the form of artefactual that presents a learning innovation curriculum in each faculty environment.

Curriculum Exhibition Room 3 is a continuation and unity with Curriculum Exhibition Room 2 and narrates a learning innovation curriculum within the Faculty of Engineering Universitas Negeri Malang. In this context, the learning innovation curriculum is narrated in the form of written blocks and presented through artifactual data of learning resources that have been experienced and traveled at the Faculty of Engineering, Universitas Negeri Malang.

The material in this room is related to the role of museums in the field of education and learning. The aim is to realize the concept of the museum today that one of the museums as a source of learning is to put forward the science and recreation, so that the museum is no longer considered as a collection of materials of ancient goods, but as a center of education or prioritizing collective memory in the past to be revived. One of them is by presenting it in an interactive learning-based audiovisual.

Design of Museum Rooms Design Room Curriculum 1 can be seen in figure 8 as follows: 


\section{B. Benchmark Visitors Flow Museum Pembelajaran Universitas Negeri Malang}

After Circulation in buildings must be arranged properly by taking into account the level of the room in the museum building. It also needs to be considered circulation settings between the circulation area, service area, main visitor area so as not to interfere with each other. In the gallery and theater function, flexible spatial design is needed so that arrangements can be made according to the function of the exhibition or show to be accommodated in it [16]. The arrangement of relations between spaces must be able to provide a clear orientation for visitors when in the museum. The determination of circulation will also be greatly influenced by the sequence of stories in the museum to be conveyed to visitors.

The determination of circulation will also be greatly influenced by the sequence of stories in the building to be conveyed to visitors [16]. Determination of circulation must be able to support the delivery of information so that it can help visitors understand and appreciate the works of art on display. This circulation arrangement will also form an atmosphere when visitors appreciate the collection of objects on display. In addition to this, the relationship between space and the functions contained in it need to be considered.

To make a set of steps, visitor traffic planning is an important factor in the design of a showroom [9]. Poor layout of the showroom can cause traffic jams, crowded spaces, confusion, disorientation and in the end visitors will lose interest in the collection. This can be avoided by providing sufficient space between the exhibits and placing important or favorite exhibits on the main circulation path. Some of the forms of circulation patterns are as follows, direct circulation patterns, open circulation patterns, radial circulation patterns, and random circulation patterns.

The circulation zone in the building is used to connect the space and activities of one to the place [17]. Continuity of circulation in the learning building will be said to be effective if the mobility of visitors can be facilitated to achieve the desired goals, from the objects discussed, it can be said with the existing circulation patterns in the old building to the new building or vice versa can be facilitated, and activities in the building can occur easily. evenly distributed between old buildings and new buildings without the creation of dead areas that are not seen by visitors. Therefore, in the preparation of the visitor flow design at the Learning Museum of the Universitas Negeri Malang, it is made to be effective and linear in order to facilitate visitor mobility.

In accordance with and in line with the results of the History of Universitas Negeri Malang research on the Visitor Flow Museum in several museums in Indonesia and the results of the museum's physical team research, the Visitor Flow Museum, the Universitas Negeri Malang Learning Museum in the form of direct circulation can be seen in Figure. It was also adjusted to 


\section{ACKNOWLEDGMENT}

the storyline of the exhibition spaces of the Learning Museum of the Universitas Negeri Malang.

Based on the Visitor Flow Museum floor plan, visitors to the museum begin by entering an open park, leading to the museum gate, reception area for visitor data collection and signs to enter museum exhibit spaces. The first session of museum visitors entered the Orientation Room of the History of Universitas Negeri Malang. Next, head to Universitas Negeri Malang History Exhibition Room and then exit through the museum's hallway to Universitas Negeri Malang Performance Exhibition Room. Furthermore, museum visitors are invited to enter Curriculum Room 1 and continue to the museum through the Universitas Negeri Malang Inscription Room to go to Curriculum Exhibition Room 2, continue to Curriculum Exhibition Room 3 and continue to the Exhibition Room of Universitas Negeri Malang in the Future, continued to the Audiovisual Exhibition Room - Interactive Learning Exhibition Room and exit through the museum aisle leading to the door to the outside and directly to the Open Garden Room. Each Museum Exhibition Room is given directions to the museum flow.

\section{CONCLUSIONS}

The The design of Visitor flow and the layout of the learning museum of the Universitas Negeri Malang is very applicable. This is based on existing data from visitors, but it is necessary to develop a more friendly visitor flow for visitors with disabilities. To showcase the museum's collection room can describe the concept of a modern museum. Visitor flow in the Learning Museum of the Universitas Negeri Malang is made to be effective and linear to facilitate visitor mobility. The distance and width of the museum are sufficient to accommodate 15 visitors in time. Walk along the museum space on the right-hand side, the museum collection display pays attention to chronological and sustainability aspects.

The layout of the collection of the learning museum of the Universitas Negeri Malang was designed using historic buildings. The layout consists of the history room of the Universitas Negeri Malang, the Profile Room of the Chancellor of the Universitas Negeri Malang, the curriculum room, the Audiovisual room, and the future UM room which has been linked to the visitor flow. In the future, the learning museum will continue to make improvements by combining elements of information and communication technology in both spatial planning and museum collection displays.
This work was supported by PNBP research grant of Universitas Negeri Malang Under Contract

\section{REFERENCES}

[1] E.N Arinze, "The Role of the Museum in Society", Public lecture at the National Museum, Georgetown, Guyana Monday, May 17, 1999

[2] Salayanti. “Analisa Pola Budaya Sunda Primodial (Pola Tiga) Pada Tata Ruang Dan Benda Pajang Di Museum Negeri Jawa Barat Sri Baduga Bandung", Jurnal I D E A L O G. Jurnal Desain Interior \& Desain Produk Vol.2 No.1, April 2017

[3] S. Bambang, "Bunga Rampai Permusiuman". Jakarta: Departemen Pendidikan dan Kebudayaan Direktorat Jendral Kebudayaan Direktorat Permuseuman, 1997.

[4] E. Hooper-Greenhill, "Museum Education dalam E. Hopper-Greenhill (ed.). The Educational Role of the Museum”, London: Routledge, 1994

[5] K. McLean, "Planning for People in Museum Exhibitions", Washington: Association of Science -Technology Centers. 1993.

[6] Y. Wahyudin, "The Application Of Storyline At Exhibition Layout At Uptd Museum Of Subang Regency", Patanjala Vol. 5 No. 3, September 2013: pp. 449 - 458

[7] A. Sachari, "Pengantar Metodologi Peneitian Budaya Rupa: Desain, Arsitektur, Rupa dan Kriya”, Jakarta: Eirlangga, 2005.

[8] A. Santosa, "Pendekatan Knseptua Dalam Proses Perancangan Interior", Jurnal Dimensi Interior. 3(2). pp 111-123, 2005.

[9] A. A. A. Wulandari, "Dasar-Dasar Perencanaan Interior Museum", HUMANIORA Vol.5 No.1, April 2014: 246-257.

[10] M. Kusyanto, "Kajian Ekspresi Eksterior Bangunan Perpustakaan Umum Kabupaten Demak", Jurnal TEKNIK UNISFAT Vol. 10 No. 2 March 2015 PP 108-114.

[11] H. Santosa, "Manajemen Arsip Inaktif sebagai Solusi Permasalahan Arsip Inaktif Tidak Teratur". Arsip Universitas Gadjah Mada : KHAZANAH ARSIP UNIVERSITAS GADJAH MADA Volumel 7, Nomor 2, July 2014

[12] H. H. Genoways, L. M. Ireland, "Museum Adiministration: An Introduction". Walnut Creek: AltaMira Press, 2003.

[13] R. M. Prastowo, H. B. Hartanti, N. Rahmah, "Penerapan Konsep Arsitektur Naratif Terhadap Tata Ruang Pameran Pada Museum". Prosiding Seminar Nasional Pakar 2019 Buku I, 2019.

[14] S. Haryoko, "Efektifitas Pemanfaatan Media Audio-Visual Sebaga alternative Optimalisasi Model Pembelajaran”. Jurnal edukasi Vol. 5, No. 1, March 2009.

[15] I.A.G.M. Indria, "Revitalisasi Museum Manusia Purba Gilimanuk Revitalization Of Ancient Man Museum Of Gilimanuk, Forum Arkeologi Volume 29, Nomor 3, November 2016, pp147-158.

[16] Natasya \& Maharani, Yuni, Pengembangan Alur Sirkulasi, Sistem Display dan Pencahayaan Pada Bandung Contemporary Art Space. Jurnal Tingkat Sarjana bidang Senirupa dan Desain.1(1). Pp. 1-9, 2014.

[17] T. Pynkiawati, S. Wahadamaputera, F, Adiwibowo, R. R. Lestari, D. P Septaningsih, "Kajian Desain Sirkulasi Ruang Dalam sebagai Sarana Evakuasi Kebakaran pada Bangunan Hotel Carrcadin Bandung”. Jurnal Itenas Rekayasa. 4(13), pp. 196-206, 2009. 